\title{
THE PERCEPTIONS OF EMPLOYEES IN A PRIVATE HIGHER EDUCATION INSTITUTION TOWARDS CORPORATE SOCIAL RESPONSIBILITY
}

\author{
FIONA MCDONALD \\ JACQUES LIEBENBERG \\ staatses@tut.ac.za \\ Department of Human Resource Management \\ University of Johannesburg
}

\begin{abstract}
This article explores the perceptions a private Higher Education Institution's employees have of Corporate Social Responsibility (CSR). Results were gathered from a selection of 19 employees at the organisation, through in depth face-to-face interviews and one focus group. Results were substantiated across both groups. A brief analysis of secondary unsolicited data was conducted to further explore the organisation's role in CSR. It was found that employees of the organisation are not positively predisposed to CSR and that many of them lack an understanding of the concept.
\end{abstract}

Key words

Corporate social responsibility, private higher education institution

It is expected of today's business organisations to display ethical and moral management in their overall business strategy. Increasing demands on business to respond to social problems and issues are important components of the current business environment. "Beyond the traditional obligation of supplying goods and services, firms now face increasing pressure on the social front" (Quazi, 2003, p. 822). Over the last few years, South African organisations are being particularly pressured into adhering to ethical and moral standards as part of their corporate governance structure (De Jongh, 2004). In addition, the terms "social responsibility", "corporate citizenship" and "corporate philanthropy" are increasingly appearing in company strategic documents and mission statements. Business leaders are thus being called to accept some accountability for social welfare (Lantos, 2001) and some are responding by embracing CSR programmes and agreements, such as the Ethical Trading Initiative (ETI) (Doonar, p. 24).

It can be argued that Corporate Social Responsibility (CSR) has arisen to enable companies to allay their feelings of guilt (Diale, 2003; Moir, 2003; Rossouw, 2002). This guilt may emerge as a result of the pure profit motive of companies often at the expense of the environment and the labour exploited in the process. This has probably been influenced by the power corporations currently wield, and the challenges that accompany this power. As Korten states (in Valor, 2005, p. 192) "corporations have been acquiring increasing power, in certain cases, even more power than some States without engaging in the advancement of the common good". However, Moir (2003, p. 7) states that "contrary to popular belief CSR is not a product of 1990s mismanagement of guilt, but has been studied as far back as the 1950s". In fact, he believes that the concept of CSR is a result of a "post-war re-examination of the nature of the relationship between business, society and governments" (2003, p. 7).

Financial markets are also starting to rate organisations in terms of their impact on society - be it environmental or social. "Corporate social responsibility theorists argue that management should incorporate ethics into strategic goals because it is the right thing to do" (Key \& Popkin, 1998, p. 331). It enables companies to use their resources to develop solutions to economic and social problems.
The need for and purpose of research into CSR

South Africa is a developing country faced with changes on both the business and social front. Organisations are directly affected by many of the social problems of the nation, such as the impact of HIV/AIDS on the workforce, economy and customers, and the lack of education under the previous dispensation. While government puts additional pressure on organisations to implement targeted affirmative action programmes, there is a dearth of skilled resources from which to draw as a result of the previous education disparities in the country. Poverty alleviation is a target of the current ANC government, and businesses are expected to contribute to this process. The recently launched JSE Socially Responsible Investment Index and the King Report on Corporate Governance are indications of the pressure on the South African corporate sector to be socially responsible (De Jongh, 2004; Hamann, Agbazue, Kapelus \& Hein, 2005). As it is, research conducted by Trialogue shows that South African businesses spent R2,35 billion on CSR in 2003, (The CSI Handbook, 2003).

Diale (2003) states that there is growing evidence of Corporate Social Investment (CSI) practice within the South African society at large. He further observes that a number of business-run foundations are being established to support this trend. South African organisations are making progress towards more CSR and similar investments, but many businesses still need to see whether benefits are in store for them as a result of these investments. Hamann et al (2005) argue that sustainable development challenges are not unique to the South African situation and that the debates related to CSR in South Africa are characterized by the particular prominence of certain priority issues, such as affirmative action, skills development and HIV/Aids" (2005, p. 5). Research conducted in other parts of the world shows that there are differing perceptions of the role that business should play in the CSR arena. As Saha and Darnton (2005) have investigated, organisations have varying responses to socially responsible issues, such as "putting their head in the sand, taking a defensive approach, paying lip service to concerns, reactive approaches, following competitors" etc. (p. 117). According to the CSI Handbook (2003), education is top of the list of social investment, with $39 \%$ of all CSR spend in South Africa targeted at this sector. 
A need thus exists to show the benefits, both socially and economically, of investing in CSR projects. In fact, Patricia Aburdene (2005) identifies the socially responsible investment boom as being one of the 'megatrends' of 2010, highlighting the importance of investigating the concept further. However, the attitude towards CSR still needs to be determined among South African organisations and their workforces. If there is an attitude that CSR is now the responsibility of the business sector because the government is ill equipped to solve the country's problems, moves towards creating more CSR investment in the country will be unsuccessful. Dominique Bé, of the European Union's directorate-general for employment, social affairs and equal opportunities, states that "the discussion about the business case (for CSR) is behind us" (in Czerny, 2005, p. 14). Through this, he implies that we need to move towards more practical actions and away from philosophizing about CSR (in Czerny, 2005). Even as legislation around the world shows more government moves to ensure businesses engage in socially responsible conduct and investments, complete participation in addressing the social problems of the country will never be reached until the correct interpretations and benefits of such CSR are explained.

Therefore, exploratory studies need to be conducted to determine the perceptions of South African business leaders and their workforce of CSR, before explanations can be made as to why these perceptions exist. Such research has been conducted in more economically developed nations to enable these attitudes to be changed. Only with the right attitude, can true CSR show benefits to both society and the corporate sector. Thus, this research could provide practitioners and other researchers with the foundation information they may need to investigate the reasons behind differing perceptions.

This study only focusses on perceptions of CSR. The purpose of this research was to conduct an exploratory study into the perceptions that the organisation's employees have of CSR, to address the need to examine these perceptions before investigating the reasons behind such perceptions. Now that these perceptions have been determined, further studies could be conducted to explain the reasons for such perceptions as an aid to developing the role business can play in CSR in South Africa.

\section{Previous research}

There is a certain amount of criticism in the management arena as to whether CSR is merely the latest politically correct management practice, especially considering that the notion of Triple Bottom Line (3BL) accounting has become more prevalent, where "a corporation's ultimate success or health can and should be measured not just by the traditional financial bottom line but also by its social/ethical and environmental performance" (Norman \& MacDonald, 2004, p. 243). Researchers such as Peter Frankental (2001) argued that CSR is a public relations invention. He stated this because he believed that organisations did not take it seriously enough - that they did not write CSR into the policies etc. "If socially responsible behaviour does not feed into a company's share price or its profits, what is the incentive for a company's leadership to pursue socially responsible policies?" (Frankental, 2001, p.19). A study conducted in 1976 into the perceptions of CSR of executives in the USA showed that these business leaders believed that their opinions and the philosophies had changed in that businesses should help to solve social problems whether or not business helps to create the problems - even if there is probably no short or long term profit potential (Abdul Rashid, 2002, p. 11).

In 1984, a similar study was conducted in the USA, by Ford and McLaughlin (Abdul Rashid, 2002) comparing perceptions of CEO's and academic leaders in the higher education sector. This study showed high agreement in both samples of corporate acceptance for social responsibility.
In 2001, Abdul Rashid's comparable study in Malaysia showed that the majority of participants agreed that "socially responsible corporate behaviour can be in the best interest of the economic shareholders" and "that efficient production of goods and services is no longer the only thing society expects from business" (2002, p. 13). In the same study, $66,2 \%$ of participants disagreed that "business already has too much social power and should not engage in social activities that might give it more". Nearly $64 \%$ of participants disagreed with the negative statement that "business leaders are trained to manage economic institutions and not to work effectively on social issues" (Abdul Rashid, 2002, p. 13).

The abovementioned research by Abdul Rashid showed that managers in Malaysia had a positive attitude towards CSR, consistent with the research conducted by Ford and McLaughlin among CEOs and Deans of Business Schools in the US in 1984.

Quazi (2003) conducted research in Australia with more investigation into the reasons for the positive attitudes of business leaders towards CSR. His research showed a high degree of positive attitudes towards CSR in Australian businesses, with a strong link to educational qualification and training, rather than physical maturity of managers. In addition, this study showed a strong correlation between religious commitment and a positive perception of social involvement.

Diale (2003, p. 1) believes that "radical change in the approach of how we go about our CSI business in South Africa needs to be revisited". He adds that certain South African businesses have done well in the CSI arena - but this cannot be said for all organisations in the country. CSR in South Africa is becoming more prominent. He states that it is not only CSR practitioners in South Africa who are interested in the subject. "How profits are generated has become a subject of scrutiny and enquiry by all those who are affected, directly or indirectly" (2003, p 1). This can be compared to McClenahen's view of American organisations where "there's a tendency to think of corporate social responsibility as philanthropy and not thinking of it in terms of what it is fundamentally about" (2005, p. 64). Further, De Jongh (2004) believes that the increased focus on CSR in South Africa has started "shifting consumers' attention towards corporate behaviour and whether it's responsible and accountable" (p. 34).

Attention is being given to the concept of CSR by the South African academic sector too, with the University of South Africa (Unisa), and the University of Natal both setting up centres and programmes respectively, dealing with Corporate Citizenship (Diale, 2003).

Such research is necessary in the South African business sector as businesses are compelled to embrace change on all levels. According to Tlakula (1999), the processes of political reform in South Africa warrant renewed attention to social problems. Government alone is not equipped to address this. However, he argues that it should be a partnership - where government and business jointly use the available resources and address social problems. As such, "renewed interest in social responsibility could emerge which will require professional management" (Tlakula, 1999, p. 8).

In fact, Mattson and Wood (2003, p. 61) state that businesses could "supplant governments in fostering a self-reliant wellbeing in society". If, according to them, the rules of business are changing, organisations should not wait until CSR is legislated. They need to take ownership of the society in which they operate, and in which their stakeholders exist, and proactively drive positive social change. In doing this, large-scale organisational change may also occur.

One can compare the role of CSR today to the role played by Affirmative Action in the early 1990s (Diale, 2003). This 
concept was not always managed. Companies who had implemented targeted Affirmative Action plans before it was legislated realised far better returns on their human investments than those who did not. Furthermore, companies that embraced and managed the process of Affirmative Action saw the direct and indirect benefits more than those organisations that applied such principles because it was required, and because it was politically correct.

Nicky Newton-King, deputy CEO of the JSE, and a contributor to the JSE Sustainability Index, believes that most companies are already doing more than necessary to tackle the country's unique challenges, and this should be recognised" (as cited in Starke, 2003, p. 30).

As such, if we take this example of Affirmative Action, sound research on CSR is required to ensure that companies are responsive to the changing face of business, and ensure that CSR is a well-managed function in every South African organisation. Previous research has shown a need to further examine the concept of CSR to accommodate the increased and potential CSR practices in South Africa (Diale, 2003; De Jongh, 2004; Hamann et al, 2005; Tlakula, 1999).

"Companies, like individuals, are expected to possess a social conscience and not only to achieve economic goals but also to use their power and influence to foster the welfare of the community" (Tlakula, 1999, p. 1). Most corporate organisations will have some kind of social responsibility programme in place - depending on what they define as CSR. It has become worthwhile to have CSR somewhere in the company activities for its reputational impact. "No corporate affairs manager will admit that their company is not socially responsible" (Frankental, 2001, p. 19). As Van de Ven and Jeurissen $(2005$, p. 301) assert: "Maybe the members of the board of directors are truly motivated by a sense of moral duty, maybe they are only backing the CSR efforts because it is good for business or themselves". The fact remains though, that there are still many companies that have a negative impact on the community in which they operate, and appear to do nothing about it. This is especially prevalent in areas, which are more remote and/or rural, and practices such as the exploitation of child labour, for example, are common.

Frankental (2001) further asserts that CSR is no more than a public relations function because of where it is situated in the organisational structure. Most often, it is located within external affairs, community affairs or corporate affairs.

Therefore, research into CSR is necessary to determine how CSR is perceived by the corporate sector, to enable further research into explaining attitudes and perceptions.

\section{Research Objectives}

This study sought to research the perceptions towards CSR of the organisation's employees to identify the company's future CSR strategy. The organisation is currently involved in CSR, but not to the degree that it affords large-scale publicity or large-scale profit returns.

This research aimed to identify the extent to which employees are aware of the organisation's various CSR interventions and whether they believe this is something they, as employees, should be more involved in?

\section{Issues to be addressed}

The research question for this study was: What do employees of the organisation perceive CSR to be? The main objective was to determine the perceptions of employees of the organisation towards CSR. A definition of CSR was provided to participants.
In brief, the objectives were:

- To determine the perceptions of the organisation's employees in terms of what they believe CSR to be;

- To determine whether these are positive or negative perceptions;

- To determine whether perceptions differ across levels of employees in the organisation.

\section{Assumptions}

It cannot be assumed that all parties have the same definition of CSR (Benson, 1978; Eberstadt in Carroll, 1977; McClenahen, 2005). As has already been stated, some organisations interpret CSR as a publicity tool, partnering with the public relations department of the business. On the other hand, there are strong views regarding the expectations of businesses when it comes to CSR. Corporate citizenship is also a term that has been associated with CSR and leads to an extended understanding of CSR (Matten \& Crane, 2005). Some authors believe that CSR should be adopted by an organisation, at all costs. In other words, returns to shareholders must be considered secondary to the investment in society. This is what Lantos (2001, p. 606) terms altruistic CSR - "genuine optional caring, even at possible personal or organisational sacrifice". For example, setting up a day care centre in a rural area would have no financial or direct benefit to the organisation at all.

As such, it is important to state clearly what CSR is - and then to allow the research results to determine whether employees see the organisation's CSR projects as altruistic or strategic.

\section{Definition of CSR}

For purposes of this research, the researcher provided the following definition to all participants: For purposes of conceptualising CSR, it can be seen as an organisation's pursuit of profit and economic progress by serving all its stakeholders government, employees, investors, customers and society, by maximising the use of its profits for the advancement of all these stakeholders.

\section{CSR in South Africa}

"The term social responsibility was introduced to South Africa in the early seventies as a result of the involvement of multinational corporations, which operated in terms of codes of employment practice" (Tlakula, 1999, p. 7). Actually, CSR, during this phase, was considered the domain of the 'personnel people' and not the 'industrialists' of business. Alternately, welfare officers were appointed to deal with the 'problem'.

Renewed interest in CSR in South Africa probably stems from the political past and the resultant social inequities and problems. As South Africa continues its process of political reform, more organisations are viewing CSR as an area of business that requires professional management.

\section{Ethical considerations}

As the research conducted dealt with the perceptions of individuals, and investigated personal tendencies towards a sensitive issue, ethical considerations were borne in mind. Babbie and Mouton (2002, p. 520) argue that "the scientist has the right to search for the truth but not at the expense of the rights of other individuals in society". This was particularly pertinent when conducting interviews as part of the research, as the guarantee of anonymity is in the hands of the researcher.

Babbie and Mouton (2002) state that qualitative research designs have the following features:

- A detailed encounter with the object of study;

- Selecting a small number of cases to be studied;

- An openness to multiple sources of data; and

- Flexible design features that allow the researcher to adapt and make changes to the study where and when necessary.

The research design for this study was based on these principles. 
While the modernist approach to research advocates valuefreedom and objectivity in social research in a quest for the truth, it also rejects any moral responsibility in an effort to make social research more scientific (Babbie \& Mouton, 2002). The post-modernist approach, however, argues that "social scientists are intrinsically linked to their social and historical contexts" and thus value-free social research is unattainable (Babbie \& Mouton, 2002, p. 40). Further, Neuman (1997) asserts that postmodernism has a strong reliance on intuition, imagination and personal experiences and that research can never completely represent what happens in the social world.

Post-modern principles have guided this study in that all social reality cannot exist outside of human reflection and inquiry (Babbie \& Mouton, 2002).

\section{Research Paradigm}

The aim of phenomenological research is to understand a phenomenon from the point of view of those people who experience it. According to Babbie and Mouton (2002, p. 271) a qualitative researcher in the phenomenological paradigm should attempt "to become more than just a participant observer in the natural setting that is being investigated". A researcher in this context needs to put him or herself in the shoes of the people under observation to understand their perceptions.

Stones (in Kruger, 1998) argues that regardless of the researcher's orientation, it is not possible to remain uninvolved when conducting social research, "for the human element is inextricably present even in the most mechanized and automated research designs, as in the interpretation and discussion of results" (p. 142). As such, in this study, I have adopted an approach which acknowledges that all the knowledge gained from this study, is influenced by my own particular point of view. My personal world-view determines my attitude towards the phenomenon of CSR, and thus supports the notion of researching a subjective reality (Stones in Kruger, 1988).

The choice to explore this phenomenon in a qualitative environment was guided by my personal scientific values of human subjectivity, and evidence suggesting that such research may uncover multiple dimensions of the topic under research (Neuman, 1997). In addition, to determine how subjects experience the world in which they work, and how actions and events in this environment directly impact on the meaning they give to this world, a qualitative methodology was appropriate. Lemon (in Du Plooy, 1995, p. 33) states that qualitative researchers believe that there is no one "objective 'reality' which can be observed and neutrally quantified. Nor do they believe that human beings are homogenous and that they can be simply categorised". Perceptions are highly individual, and it is thus not always possible to capture these in a highly generalised manner. The aim of this research was to determine such perceptions only - not to show any correlation with any other variables.

\section{Case Study Design}

De Vos (2002) believes that a case study can examine processes or events, or people and cites Stake (in De Vos, 2002, p. 275) as stating that "the sole criterion for selecting cases for a case study should be 'the opportunity to learn'". It enables an investigation of a single unit - in this case an organisation (Babbie \& Mouton, 2002). The selection of a case study setting was guided by the purpose of the research, as it allows for exploration and differing methods of data collection. The decision to examine this phenomenon of CSR in a case study setting was further guided by my personal circumstances. At the time the research was conducted, I was employed by the case study organisation and was responsible for its CSR activities. Thus, it was beneficial to me as well as to the organisation to study CSR in this particular organisation.

\section{RESEARCH DESIGN}

\section{Research Approach}

The organisation selected for this study was a private higher education institution, part of a larger private education Group, based in Johannesburg, South Africa. At the time of the study the organisation had 100 employees across executive, management, academic, administrative and elementary levels. At the time of the research the organisation was undergoing significant change and restructuring, as a result of a merger.

\section{Selection of participants}

The population identified for this study was all functionally literate employees of a private higher education institution. Employees with low literacy were excluded in this study. As the focus of this study was on the perceptions of all employees across all levels, it was important that the sample included a range of employees from the elementary levels to senior management, within the defined parameters, to ensure representativeness (Durrheim, 1999).

Purposive sampling was used to ensure that the sample was representative of these levels, as this study was assessing perceptions of CSR across all organisational levels (Strydom \& Delport, 2002). Babbie \& Mouton (2002) state that purposive sampling is appropriate when the researcher's knowledge of the population will enable him/her to ensure that the sample is most representative of the population. De Vos (2002, p. 207) further argues that purposive sampling enables a sample that contains "the most characteristic, representative or typical attributes of the population". Thus, it ensures that the techniques used to construct the sample will ensure that the purpose of the research is upheld.

Therefore a sample of 19 participants was selected on the following basis:

- 4 elementary employees

- 5 administrative employees

- 3 academic employees

- 2 academic heads of department

- 3 administrative heads of department

- 2 executive employees

Bearing these criteria in mind, participants were selected on a random basis within each department provided they met the purposive sampling criteria.

Entry to the research setting

Entry to the research setting was gained via permission from the then Managing Director and executive committee. The purpose and context of the research was explained to selected participants as was the method of participant selection. As I, as researcher, was known to all participants, there was no resistance to me using these participants in the study. Thus permission was gained at the organisational level as well as the individual level (Schurink, 2005).

\section{Research Methodolgy}

Multiple methods of data collection were used in this study. Data was collected by means of in-depth face-to-face interviews with the sample selected, followed up with focus groups comprising different participants. In addition, participant observation was selected to reveal important information not overt in an interview or focus group (Cresswell, 1998; Greef, 2002; Neuman, 1997).

Interview questions were open-ended to encourage further discussion by the participants. Similar types of questions were used in the focus groups.

Participant observation was particularly relevant to this study as the researcher was "somewhat socialised into the social setting in which the observation was being done" (Baker, 1999, p. 246). 
As a result of my role as both executive in the organisation, as well as researcher, I was able to approach the research as both participant and observer. This participation was overt.

Secondary sources of information used included available unsolicited documents at the company, including strategic plans, the company Mission Statement, the company Values Charter, and the company CSR budget allocation, to ensure triangulation of the data collected (De Vos, 2002; Strydom \& Delport, 2002).

\section{Limitations}

One of the major potential limitations of the data collection is that the participants were not anonymous. Certain participants may have been intimidated in the research setting, particularly in the presence of the researcher who previously occupied an executive position at the organisation.

In an attempt to overcome this potential limitation, the context of the research was explained to all participants so that they understand that any implications arising from the data gathered would not reflect negatively on them. It was not considered necessary to conduct formal peer debriefing at the conclusion of the data collection phase, as the researcher had since left the employ of the organisation and would not be interacting with the subjects in any way thereafter.

\section{Research Procedure}

The procedures used for gathering data were guided by phenomenological principles. Unstructured in-depth interviews were conducted with individual participants. After analysis of this data, focus group sessions were held with the participants in a group setting.

Concurrent analysis of unsolicited documents was analysed throughout the data collection phase. The company has in existence an organisational strategic plan, a Values Charter, a mission statement and financial reports indicating CSR spend at the company. An in-depth analysis of this data took place to determine the strength of the CSR profile.

Results were recorded on tape and then transcribed into paper documents, thus minimizing the need to take notes during the interviews and focus group. Secondary unsolicited documents were duplicated and kept for analysis. Athens (as cited in Schurink, 2005) asserts that "the way in which a researcher makes a study credible is by supplying an adequate account of his or her research along with the description of its results". While a complete account of all observations was not possible in this context, the recording of data in this way contributes to ensuring the soundness and quality of the research (Schurink, 2005).

\section{Data Explicitation}

Data collected was analysed by means of identifying similar emergent themes around the concept of CSR. Individual and common meanings were sought as a means of exploring the perceptions participants have of CSR (Mouton, 2002). Reasons for these meanings will not be analysed in any way. This is an area for further research for explanatory purposes.

In keeping with the methodology for data explicitation of Groenewald and Schurink (2003), the term "explicitation" has replaced the term "analysis" on Hycner's (1999, p. 161) recommendation. Hycner (1999, p. 161) argues that the term "analysis" has dangerous connotations for phenomenology in that it implies a "breaking into parts' and therefore often means a loss of the whole phenomenon". The term 'explicitation' implies an "investigation of the constituents of a phenomenon while keeping the context of the whole" (1999, p. 161). This method lends itself to a more interpretative manner of scrutinising the data.
Data explicitation thus took place within a phenomenological paradigm, as used by Groenewald and Schurink (2003), and followed five distinct stages:

- Bracketing and phenomenological reduction

- Delineating units of meaning

- Clustering units of meaning to form themes

- Summarise each interview, validate and modify

- General and unique themes for all the interviews

\section{RESULTS}

\section{Interviews and focus group}

The results of the study show that the perceptions of CSR amongst the organisation's employees differ significantly. There was a discrepancy as to how the participants understood the concept of CSR. Very few participants had actually given some thought to the concept prior to the interview/focus group. This said however, most participants agreed with the definition presented to them for the purposes of this study. Some of them were not familiar with the profit motives behind the practices of CSR and questioned the relevance thereof. For example, one participant stated the following: "I am concerned about using the words 'maximising the use of profits' - I am not sure my organisation is doing that". Another participant used the words: "I don't know how CSR is linked to economics". Most participants agreed with all the listed stakeholders but some suggested that the order in which stakeholders are listed in the definition is misleading and ranks stakeholders in terms of priority.

There was some confusion as to whether CSR should be a budgeted expense, or should come after profit is declared, and only if profit is realized. Participants generally felt that it should be budgeted for, but at the same time, CSR should not be at the expense of the company. Any company needs to make a profit first, and then engage in social investment. One such participant stated: "I think organisations should invest in CSR before they take a profit. It should be seen as an everyday expense". However, it is my belief that without profit, an organisation will not be in a position to engage in CSR projects.

Furthermore, almost all participants see CSR as somewhat internally focussed, and I observed that there was often confusion between human resource practices and CSR. While there seems to be some understanding of the role of an organisation as being socially responsible to its employees, the practices associated with this are confused with human resources practices. For example, what would normally be considered an employee benefit is confused with being a CSR intervention for employees. Participants felt that staff morale was low, and that caring for one's staff was a social responsibility intervention as opposed to being a human resource practice. One participant also noted that the salary one is paid for work done is a socially responsible practice on the part of the employer.

Some participants were not knowledgeable about CSR in South Africa. Most participants could identify South African, and even international, organisations who have a high CSR profile, but very few could actually provide details on the kinds of projects in which these organisations are involved. Organisations listed were mostly large SA organisations such as Vodacom, Shell, Nedbank, Standard Bank, MTN, and ABSA.

Furthermore, participants had differing perceptions on the role and prevalence of CSR in SA. Many felt that SA is still a developing nation in this respect, and is doing as much as is possible to address the social issues of the country. However, there was a strong perception that SA organisations are investing in CSR for their own benefit, rather than for the country to benefit. One participant referred to it has evoking 
a "fuzzy, warm feeling" of doing good, but it is not necessarily perceived as doing good for the right reasons. Very few participants recognised it as being a compliance issue in terms of corporate reporting.

Many participants also felt that customers are putting pressure on organisations to become more socially responsible. Customers may prefer to patronize suppliers who are known for investing in the community. Participants also believed that this was linked to the profit motive behind CSR, as more CSR will result in more customers.

Participants cited reasons for corporations becoming involved in CSR as anything related to publicity, marketing, free advertising, ethics, legislative compliance and exposure. Participants did not believe that organisations invested in CSR projects for pure philanthropic reasons. One participant stated: "Well I think it is an image thing - they think it is good for their image. They wouldn't do it if they won't benefit from it". It was largely felt that these organisations invest as such to obtain some kind of exposure and to be seen as doing the 'right' thing or keeping up with global best practices and international pressure. Furthermore, one participant referred to CSR as being a reaction to "white guilt", while another stated that "it touches on ethics".

On an individual level, CSR was important to all participants. Many felt that any small contribution classifies as socially responsible behaviour, and that people should look to their own immediate environment before trying to reach out to a larger community. However, there was no consistency in the participants perception of how important CSR was to an individual seeking a job in SA. For example, when asked whether an organisation's CSR profile would influence whether they accepted employment at that organisation or not, the responses were varied. For some participants, it was felt that an organisation that has a strong commitment to CSR will also have a strong commitment to its employees, and association with that organisation will instill a sense of pride in employees. However, many participants also commented that the current economic climate in SA does not make it possible for people to choose employers based on CSR profiles. It was felt that the SA commercial environment is not 'mature' enough yet for such trends. While CSR was important to the individual, most people are not in a position to choose between jobs - they take what they can get.

When questioned on the potential beneficiaries of CSR in SA, most participants required additional information. I observed that participants were not entirely clear on the definition and thus could not easily identify stakeholders. However, for the most part, it was agreed that the community, NGO's, NPO's, the underprivileged and employees benefited directly from CSR interventions. There was much debate surrounding the notion of the government benefitting from CSR. Some participants felt that the private sector organisations are doing the job of the government when the government should be using tax income to uplift society. Others felt that the government did benefit from CSR, and that this was not necessarily negative. These participants believe that all members of SA society should be contributing to CSR in some way as the country as a whole will benefit in the long term.

Participants generally agreed on the high need areas requiring CSR intervention. Responses covered areas such as HIV/AIDS, crime, rape, child abuse, and education. Education and skills development featured most prominently. One participant also referred to the needs of the elderly as an area requiring attention. The environment featured in a minor way.

On a more specific level, participants mostly felt that their own organisation was sufficiently contributing to community projects and CSR interventions. None of the participants felt that the organisation should be doing less CSR. However, this must be interpreted in conjunction with how participants understood CSR in terms of employee benefits. After some discussion and probing, participants agreed that some practices at the organisation are more CSR issues, and they agreed that others were purely human resource issues. In general, participants felt that the organisation's CSR had both an internal and external impact.

\section{Themes}

Several themes were addressed around the organisation's CSR activities and how staff perceived these. This was done to determine the culture of acceptance of CSR at the organisation. All participants felt that the organisation was engaged in good practices, but they agreed that there were employees who feel that the investment should go to staff first, before the community is assisted.

From the results, the following 3 themes emerged as significant to the results:

- Definitions of CSR

- Perceptions of CSR in South Africa

- Participant's perception of the organisation's role in CSR

All results gathered can be clustered into the following themes from which to draw analyses. Figure 1 shows responses from interviewees according to the above themes:

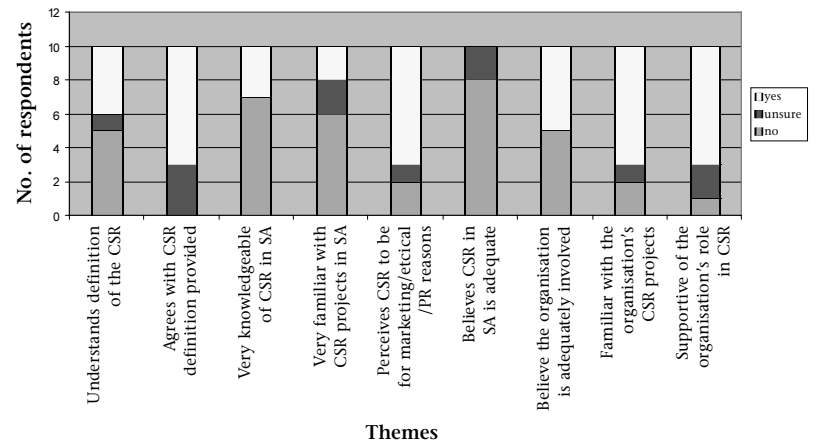

Figure 1: Interview responses to themes

Table 1 refers to the overall impressions of focus group participants and compares these responses to the majority responses of interview participants.

TABle 1

COMPARISON OF FOCUS GROUP AND INTERVIEW REPSONDENTS TO THEME

\begin{tabular}{llc}
\hline & $\begin{array}{l}\text { Interview } \\
\text { average }\end{array}$ & $\begin{array}{l}\text { Focus } \\
\text { group }\end{array}$ \\
\hline Do not understand definition of CSR & no & no \\
Agree with CSR definition provided & yes & yes \\
Very knowledgeable of CSR in SA & no & no \\
Very familiar with CSR projects in SA & no & yes \\
Perceive CSR to be for marketing/ethical/PR reasons & yes & yes \\
Believe CSR in SA is adequate & no & no \\
Believe the organisation is adequately involved & yes/no & no \\
Familiar with the organisation's CSR projects & yes & yes \\
Supportive of the organisation's role in CSR & yes & yes \\
\hline
\end{tabular}


What becomes evident after the above comparison is that data gathered from the focus group mostly supports data gathered from the interviews. A significant conclusion may be drawn from the two themes where there was a discrepancy in the overall response. The focus group participants proved to be more familiar with CSR in South Africa than the interview participants. I assume that the dynamics of a focus group have caused this difference in perception. There was more discussion around CSR in SA in the focus group, thus triggering more thoughts about the theme. I observed that when examples of SA companies involved in CSR were mentioned in the focus group, more ideas emanated from participants. This is a natural phenomenon occurring in focus groups. However, in the interviews, I did not give any examples of SA companies involved in CSR projects, hence forcing participants to develop responses based on their own knowledge and not on that of fellow participants.

The focus group results also differed from the interview results with regard to the involvement of the organisation in CSR. The focus group participants did not believe that the organisation was adequately involved in CSR, whereas the interview participants were divided on their responses. I can assume that the focus group scenario may be more intimidating for an individual who reveals personal perceptions on a sensitive issue. The focus group was of the opinion that not enough was being done by the organisation, and some of the stronger participants in the focus group stressed this more than others.

Participants were generally aware of CSR projects running at the organisation but felt that the communication around these projects could be better to ensure that all employees knew what interventions were in place. In addition, participants felt that very little involvement was required of employees in the organisation's CSR projects, and expressed that this was an area for improvement. One or two main projects emerged as most significant for participants.

Several questions were directed towards the participants with regard to their perceptions of the organisation being a caring company. I did this to determine perceptions towards the organisation and to determine whether this has an impact on how staff perceive CSR. The participants were again polarised on this issue. While some felt that the organisation was a very caring company, others felt that it did not treat its staff well.

While some participants had limited involvement in community work or CSR projects, most participants were not formally involved in any such projects. This issue was addressed with participants to determine a predisposition towards CSR, or prior knowledge, as this may affect perceptions of CSR

One of the objectives of the study was to identify whether perceptions differ across employment levels. The results gathered reveal that lower level employees are not as aware of the concept of CSR as the higher level employees. They view it on a micro environmental level only, and not in the broader SA society. In addition, each participant at an elementary or lower administration level in the organisation perceives CSR as a good thing, and believes it is important to them.

Academic staff were more verbal about the role of CSR as well as the definition of CSR presented to them. These participants questioned the definition of CSR more than the elementary employees did, and also demonstrated a higher level of comprehension of the definition of CSR and the associated interview questions.

The focus group conducted after the interviews showed the same trends. Elementary staff knew less about the concept and offered less opinion during the discussion.

\section{Secondary data}

The organisation does not have a dedicated CSR strategy guiding its CSR activities. CSR is also not mentioned in its overall strategic planning documentation. However, the organisation embarked on a Values Charter planning project in 2003, out of which emerged a set of core values guiding all organisational behaviour, planning and strategies. A list of values were identified by Executive staff, after which this list was presented to staff for the final decision. Staff voted on the values and Social Responsibility was identified as a core value for the organisation.

There is no dedicated CSR budget as most of the projects in which the organisation is involved focus on the provision of free education, which requires no financial outlay by the organisation. Further, most employees volunteer their time and services in such projects.

However, around 1\% (R500 000) of the total revenue of the organisation is allocated to the provision of bursaries to, among others, financially needy students.

\section{DISCUSSION}

\section{Emerging perceptions}

Once captured, all results were examined to extricate patterns and themes around the perceptions of CSR. The main areas of focus were guided by the research objectives and thus were grouped according to theme.

\section{Importance of CSR}

The results suggest that the organisation's employees' perceptions of CSR overall are neither informed, nor overtly positive, and that the organisation's employees are not particularly positively predisposed to CSR. While most participants felt that CSR was considered important to them as individuals, they did not feel so strongly to allow it to influence their choice of employment. The same trends emerged from the focus group. Very few participants were, or had been, involved in community work or CSR-type projects at the time of the interviews and focus groups. I can thus assume that the participants want to believe CSR is important to them, but on probing with related questions, it emerged that very few participants put into practice what they state are their beliefs.

Figure 2 indicates the breakdown of responses gathered.

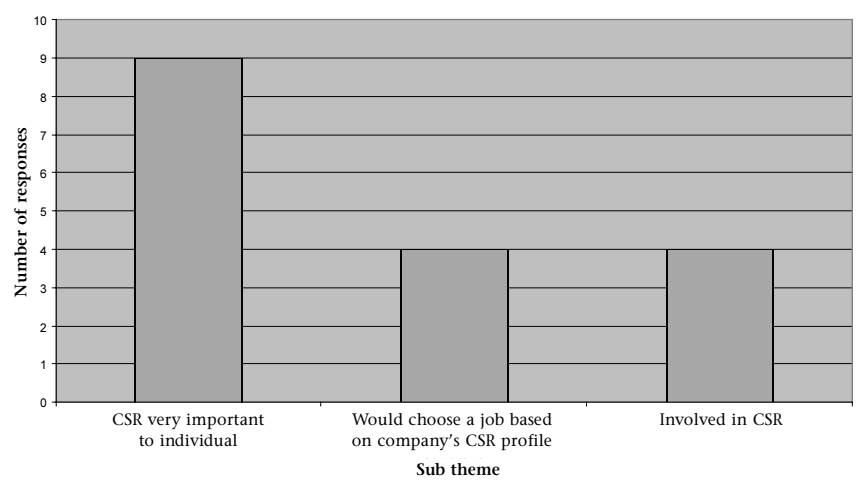

Figure 2: Interview responses to importance of CSR

Participants gave the impression that the organisation should be focussing more internally before engaging in external CSR interventions. I assume from the data gathered that participants would prefer the broader organisational issues to be resolved before CSR is afforded priority. Based on the results, participants were not overtly resentful of the CSR activities of the organisation, yet their responses to certain statements indicated that staff were not as predisposed to CSR as they intended to convey. 
From this emerges the notion that participants need to move away from feelings of guilt, to a level of understanding of CSR. When this is achieved, the concept of CSR as being a way of sharing resources and wealth will be better understood.

\section{Reasons for engaging in CSR}

The results gathered lead to the assumption that CSR is considered to be a marketing or publicity opportunity for companies engaging in such interventions. This supports some research already conducted in this area, as discussed in the literature survey.

The evidence further suggests that the CSR activities at the organisation are not co-ordinated in any manner, and that there is no clear communication strategy with regards to CSR. In addition, secondary document analysis revealed that there is no targeted CSR strategy at the company, neither is there a dedicated CSR budget. These results indicate that the participants in the interviews and focus groups were correct in their perception that the organisation's CSR is lacking direction. I can thus assert that CSR at the organisation is not part of the organisation's policy and is thus perhaps not "taken seriously enough" (Frankental, 2001).

\section{CSR in South Africa}

The research conducted in this study shows that participants perceive the SA corporate industry to not yet have reached a level of maturity with regards to CSR to see it as a strategic and significant part of the business. This supports prior research into CSR in SA that indicates that SA organisations should be managing CSR in a more professional manner.

From the results of the study, I can assume that either there is not enough CSR happening in SA to have a significant impact on participants, or that such projects are not communicated as widely as they should be. In addition, some participants suggested that the public never hear of the direct beneficiaries of CSR in SA. This again supports my assumption that the exposure gained for a company through such projects is more important to the company than the actual benefits to the stakeholders, thus contributing to the negative perceptions of CSR held by participants.

\section{Summary of perceptions}

From these results, I believe that there is no common understanding of CSR in SA amongst participants, or a common appreciation of the need for CSR. Participants generally confused CSR with human resources issues and felt that employee benefits and employee assistance programmes should be primary areas of CSR focus within the organisation. There was also a general tendency amongst participants to assume that CSR was more about spending money, than investing in a socially responsible manner.

It is important to note that at the time of the interviews and focus groups, the organisation was involved in a large scale restructuring and change intervention, resulting in instability and uncertainty within the workforce. This could explain why many human resources issues emerged in the discussions, and why there seemed to be hidden negativity towards the organisation's support for its own staff.

That aside, however, the emerging themes as listed above can be cross referenced as follows:

There was no clear understanding of CSR amongst recipients, resulting in somewhat negative or uninformed perceptions of CSR in SA. This further resulted in the same perceptions emerging with regards to the organisation itself, however, these were not overtly expressed. I can assume that this was because I was a senior executive at the organisation and participants may not have felt comfortable making negative comments about their organisation.
Figure 1 compares the overall positive and negative responses given. Responses were classified according to Table 1. For purposes of this research, all uncertain responses were classified as negative, as they indicated an inherent lack of understanding or knowledge.

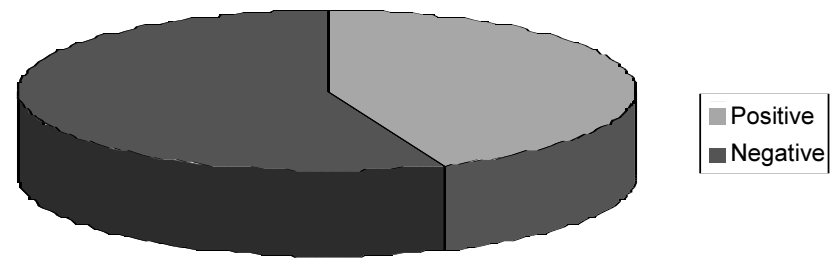

Figure 3: Comparison of positive and perceptions of CSR

I may make assumptions as to the reasons for the lack of understanding of CSR, based on the participants' limited knowledge of the concept. For many participants, they only developed a rudimentary understanding of the term after the interview or focus group commenced.

\section{Conclusion}

My own perceptions reveal that CSR is a concept that is not well understood, and thus the negative perceptions surrounding it beg explanation. I also believe that the emotional context of the participants played a role in conveying a negative perception, and it was extremely difficult for both myself, as well as participants to create an element of distance. From this research, however, my own view of the role CSR plays in society is somewhat different. The lack of awareness around this concept has highlighted the shortcomings of both government and the corporate sector, and the role they play in the CSR arena. This said, I still believe that the research is sound, and represents the perceptions of the selected participants accurately.

There are still differing understandings of the meaning of CSR, which causes certain perceptions to emerge. The study set out to establish what these perceptions were, to explore the concept of CSR in SA in a more scientific manner. Reasons for these perceptions cannot be scientifically assumed at this point and further explanatory research must be conducted to examine these reasons.

\section{REFERENCES}

Abdul Rashid, Z. (2002). Executive and management attitudes towards corporate social responsibility in Malaysia. Corporate Governance, 2, (4).

Aburdene, P. (2005). Megatrends 2010: The rise of conscious capitalism. Charlottesville: Hampton Roads Publishing Company.

Babbie, E \& Mouton, J. (2002). The practice of social research. Cape Town: Oxford University Press.

Baker, T.L. (1999). Doing social research. USA: McGraw-Hill.

Benson, C.S. (1978). Business Ethics in American Society. USA: Claremont Men's College Publishers.

Carroll, A (1977). Managing Corporate Social Responsibility. Boston: Little, Brown and Company.

Cresswell, J.W. (1998). Qualitative inquiry and research design. Thousand Oaks: Sage.

Czerny, A. (2005). Time for action on proven business case for CSR. People Management, June 2005.

De Jongh, D. (2004). Know your stakeholders. Finance Week, June 2004.

De Vos, A.S. (Ed). (2002). Research at grass roots. Pretoria: Van Schaik.

Diale, T. (2003, September). Relooking at Corporate Social Investment in South Africa. Moneyweb. Pp 1-4. Retrieved January 29, 2004 from the World Wide Web: http://m1.mny.co.za/mnsbx.nsf. 
Doonar, J. (2005). A question of ethics. Brand Strategy, June 2005.

Du Plooy, G.M. (Ed.) (1995). Communication Research. Cape Town: Juta.

Durrheim, K. (1999). Research in practice: applied methods for the social sciences. Cape Town: University of Cape Town Press.

Frankental, P. (2001). Corporate social responsibility - a PR invention. Corporate Communications: An International Journal, 6, (1).

Greeff, M. (2002). Research at grass roots. Pretoria: Van Schaik.

Groenewald, T \& Schurink, W. (2003). The contribution of cooperative education in the growing of talent in South Africa: A qualitative phenomenological exploration. SA Journal of Human Resource Management, 1 (3).

Hamann, R. Agbazue, T. Kapelus, P \& Hein, A. (2005). Universalising corporate social responsibility? South African challenges to the international organisation for standardisation's new social responsibility standard. Business and Society Review, 110 (1).

Hycner, R.H. (1999). Some guidelines for the phenomenological analysis of interview data. London: Sage.

Key, S \& Popkin, S.J. (1998). Integrating ethics into the strategic management process: doing well by doing good. Management Decision, 36, (5).

Kruger, D. (1988). An introduction to phenomenological psychology. Johannesburg: Juta.

Lantos, G.P. (2001). The boundaries of strategic corporate social responsibility. Journal of Consumer Marketing, 18, (7).

Matten, D \& Crane, A. (2005). Corporate citizenship: toward and extended theoretical conceptualization. Academy of Management Review, 30 (1).

Mattson, M \& Wood, D. (2003). Beyond the triple bottom line: Towards a conscious model of corporate governance. Leadership, October 2003.
McClenahen, J.S. (2005). Defining social responsibility. Industry Week, March 2005.

Moir, L. (2003). The business world's latest buzzword?: CSR and what it means to you. Strategic Direction, 19, (6).

Mouton, J. (2002). Understanding social research. Pretoria: Van Schaik.

Neuman,W.L. (1997). Social research methods: Qualitative and quantitative approaches. USA: Allyn \& Bacon.

Norman, W \& MacDonald, C. (2004). Getting to the bottom of "triple bottom line". Business Ethics Quarterly, 14 (2).

Quazi, A.M. (2003). Identifying the determinants of corporate managers' perceived social obligations. Management Decision, 41, (9).

Rockey, V. (Ed.) (2003). CSI Handbook. Cape Town: Trialogue.

Rossouw, D. (2002). Business Ethics in Africa. Cape Town: Oxford University Press.

Saha, M \& Darnton, G. (2005). Green companies or green conpanies: Are companies really green or are they pretending to be? Business and Society Review, 110 (2).

Schurink, W. (2005). Evaluating qualitative research. Unpublished lecture notes.Starke, A. (2003). Socially responsible investing and the launch of a South African index. Leadership, September 2003.

Starke, A. (2003). Socially responsible investing and the launch of a South African index. Leadership, September 2003.

Strydom, H \& Delport, C.S.L. (2002). Research at grass roots. Pretoria: Van Schaik.

Tlakula, L.B. (1999). An investigation into corporate social responsibility: The case of Coca-Cola. Masters Dissertation: Milpark Business School.

Valor, C. (2005). Corporate social responsibility and corporate citizenship: Towards corporate accountability. Business and Society Review, 110 (2).

Van de Ven, B \& Jeurissen, R. (2005). Competing responsibly. Business Ethics Quarterly, 15 (2). 